\title{
The Failure of E-government in Jordan to Fulfill Potential
}

\author{
Raed Kanaan \\ Faculty of Informatics \\ Amman Arab University \\ Amman, Jordan
}

\author{
Ghassan Kanaan \\ Faculty of Informatics \\ Amman Arab University \\ Amman, Jordan
}

\begin{abstract}
The aim of this paper is to uncover the reasons behind what so-called total failure in e-government project in Jordan. Reviewing the published papers in this context revealed that both citizens and employees do not understand the current status of this program. The majority of these papers measure the quality of e-services presented by e-government. However, according to the minister of Communication and Information Technologies (MOCIT), only three e-services are provided by this program up to writing this paper. Moreover, he decided to freeze the current working on e-government programme. These facts drove the authors to conduct this research. General review of the existing literature concerning e-government implementation in Jordan was applied, then a qualitative research was utilised to uncover the reasons behind the failure of the e-government program in Jordan. The collected data then was analysed using Strauss and Corbin's method of grounded theory. This paper illustrates that Jordanian government need to exert strenuous efforts to move from the first stage of e-government implementation into an interactive one after fourteen years of launching the program, considering that only three e-services are presented up to October 2013. Reasons behind the failure of egovernment in Jordan have also been identified.
\end{abstract} failure

Keywords-e-government; grounded theory; Jordan; total

\section{INTRODUCTION}

E-government has become a focus of government efforts in several countries around the world. Jordan was one of the first developing countries that started e-government implementation in the year of 2000 .

E-government can be defined as "the carrying out of governmental activities using Information and Communication Technology tools in order to deliver better services to citizens, businesses and government entities (including government employees)" [1]. Therefore, e-government is expected to improve efficiency, transparency and effectiveness of the services provided by government departments to citizens, businesses and government itself [2] [3].

Several benefits and advantages of e-government have been listed repeatedly in the literature, table 1 summarises these benefits for both developed and developing countries from different perspectives:
TABLE I. BENEFITS OF E-GOVERNMENT IMPLEMENTATION (ADAPTED FROM [1])

\begin{tabular}{|c|c|c|}
\hline Perspective & Benefits & Source \\
\hline Government & $\begin{array}{l}\text { Reducing errors } \\
\text { Saving time and money } \\
\text { Reducing bureaucracy } \\
\text { Improving the quality of } \\
\text { services } \\
\text { Increasing economic } \\
\text { competitiveness } \\
\text { Increasing accountability } \\
\text { Driver for other companies }\end{array}$ & {$[4][5][6][7][8]$} \\
\hline $\begin{array}{l}\text { Citizen and } \\
\text { businesses }\end{array}$ & $\begin{array}{l}\text { Services available 24/7 } \\
\text { Increasing citizen } \\
\text { participations in } \\
\text { government decision } \\
\text { making } \\
\text { Bridging the digital divide } \\
\text { Increasing transparency }\end{array}$ & {$[9][10][11][12][13]$} \\
\hline
\end{tabular}

In order to achieve the above mentioned benefits, several stages of the e-government implementation need to be followed in. There are different stage models in the literature as described in table 2:

\section{TABLE II. E-GOVERNMENT STAGES (ADAPTED FROM [1])}

\begin{tabular}{|l|l|l|}
\hline \multicolumn{1}{|c|}{ Stages } & \multicolumn{1}{|c|}{ Definition } & Source \\
\hline Publish & $\begin{array}{l}\text { Presenting } \\
\text { government } \\
\text { information online to } \\
\text { citizens. }\end{array}$ & [14] \\
Two wact & $\begin{array}{l}\text { communication } \\
\text { between government } \\
\text { and citizens and their } \\
\text { involvement in } \\
\text { government } \\
\text { processes. }\end{array}$ \\
Transact & $\begin{array}{l}\text { Conducting all } \\
\text { transactions online. }\end{array}$ & \\
\hline
\end{tabular}




\begin{tabular}{|c|c|c|}
\hline Cataloguing & $\begin{array}{l}\text { Presenting } \\
\text { government } \\
\text { information online } \\
\text { via web sites. }\end{array}$ & {$[15]$} \\
\hline Transaction & $\begin{array}{l}\text { Citizens interact with } \\
\text { government } \\
\text { electronically. }\end{array}$ & \\
\hline Vertical integration & $\begin{array}{l}\text { Local systems linked } \\
\text { to higher level } \\
\text { systems. }\end{array}$ & \\
\hline Horizontal integration & $\begin{array}{lr}\text { Systems } & \text { integrated } \\
\text { across } & \text { different } \\
\text { functions. } & \\
\end{array}$ & \\
\hline Information publishing & $\begin{array}{l}\text { Each government } \\
\text { department creates a } \\
\text { web site. }\end{array}$ & {$[16]$} \\
\hline Official two-way transactions & $\begin{array}{l}\text { Citizens make } \\
\text { electronic } \\
\text { transactions such as } \\
\text { paying tax and } \\
\text { buying TV licenses. }\end{array}$ & \\
\hline Multi-purpose portals & $\begin{array}{l}\text { Creation of a single } \\
\text { point (portal) to } \\
\text { enable citizens to } \\
\text { access and obtain } \\
\text { government } \\
\text { information } \\
\text { services. }\end{array}$ & \\
\hline Portal personalisation & $\begin{array}{l}\text { Citizens have the } \\
\text { ability to customise } \\
\text { portals according to } \\
\text { their needs. }\end{array}$ & \\
\hline Clustering of common services & $\begin{array}{l}\text { Government } \\
\text { departments will } \\
\text { disappear when the } \\
\text { portals become } \\
\text { better. }\end{array}$ & \\
\hline $\begin{array}{l}\text { Full integration and enterprise } \\
\text { transformation }\end{array}$ & $\begin{array}{l}\text { Fully better changing } \\
\text { in government } \\
\text { departments. }\end{array}$ & \\
\hline Presence & $\begin{array}{l}\text { Presenting web sites } \\
\text { and providing } \\
\text { information about } \\
\text { departments. }\end{array}$ & [17] \\
\hline Interaction & $\begin{array}{l}\text { Downloading } \\
\text { electronic forms. }\end{array}$ & \\
\hline Transaction & $\begin{array}{l}\text { One-way } \\
\text { communication. }\end{array}$ & \\
\hline Transformation & $\begin{array}{l}\text { Two-way } \\
\text { communication, } \\
\text { streamlining } \\
\text { procedures. }\end{array}$ & \\
\hline
\end{tabular}

\begin{tabular}{|c|c|c|}
\hline Information & $\begin{array}{l}\text { Government posts } \\
\text { information on its }\end{array}$ & [18] \\
\hline Two-way communication & $\begin{array}{l}\text { Citizens } \\
\text { communicate online } \\
\text { with Government } \\
\text { and they can fill in } \\
\text { forms and request } \\
\text { information } \\
\text { services. }\end{array}$ & \\
\hline Transaction & $\begin{array}{l}\text { All transactions } \\
\text { conducted online. }\end{array}$ & \\
\hline Integration & $\begin{array}{l}\text { Citizens can access } \\
\text { all services via } \\
\text { single portal. }\end{array}$ & \\
\hline Participation & $\begin{array}{l}\text { Political participation } \\
\text { such as voting } \\
\text { online, and } \\
\text { participating in } \\
\text { decision making by } \\
\text { posting comments } \\
\text { and suggestions. }\end{array}$ & \\
\hline
\end{tabular}

However, researchers still argue that e-government has not yet reached the promise of the above mentioned benefits especially in developing countries. Reference [19] stated that barriers to the successful implementation of e-government are related to the failure of a government to accomplish fundamental requirements supporting the initiative of egovernment. Moreover, [20] described e-government program in developing countries as a recipe for failure. He defined the failure as the "inability of such a system to achieve predefined goals or other, previously unanticipated benefits (p.2)". That could be the case in Jordan due to the fact that the initiative was never implemented or was implemented but immediately abandoned [21]. This paper therefore aims to provide an insight to the core reasons behind the failure of e-government project in Jordan since there are only three e-services presented by the program from 2000 to 2013, according to the minister of CIT.

\section{LITERATURE REVIEW ON JORDAN AND IT's E- GOVERNMENT PROGRAM}

Jordan is a relatively small country of 7,371,000 million people. It is located in the Middle East within a total area of 92,300 Square Kilometres, the vast majority of which is either desert or semi-arid. Jordan neighbouring countries include Iraq, Israel, Saudi Arabia, Syria and the West Bank [22], and the whole area can be described as "volatile".

As part of the king's strategy for economic growth, the Jordanian government embarked on a major long-term egovernment initiative in the year 2000. The project aimed to deliver positive change to both government and its services, by improving service delivery, enhancing responsiveness to customer needs, increasing transparency (and thus reducing the potential for corruption) and efficiency of operations, and enhancing the level of understanding of ICT in general with Jordanian society [23]via the use of e-government. 
However, thirteen years on and the e-government project in Jordan still falls predominantly within the informational and publishing stage of e-government evolution [18] [14] as described in the next paragraphs. For instance, [24] an egovernment readiness assessment model was proposed basing on six factors. These factors are as follows: organizational readiness, governance and leadership readiness, customer readiness, competency readiness, technology readiness, and legal readiness. They studied each factor and resulted in some important issues that need to be considered before implementing e-government in Jordan. They claimed that "EGovernment implementation will not face major barriers if Jordanian government adopt their model and/or take into consideration the unsolved problems in each of the above mentioned six factors.

Reference [25] studied the e-government implementation progress by evaluating the strength and weaknesses in selected government websites. They referred to the limitation in the online business as a result of the lack and absence of local certificate in Jordan. They concluded that private sector needs to get involved in building the required infrastructure of the egovernment. In addition, they asserted that increasing the awareness of the customers on how to practice e-business is an important factor in successful e-government in Jordan. Furthermore, [26] when examined G2B practices in Jordan, they suggested that government should increase the number of internet users before moving toward more advanced level of egovernment implementation. However, even if the internet users have been increased there are no available e-services to be used by the citizens or businesses. Nonetheless, [27] and [25] considered the e-services being provided by banks or the private sector as part of e-government services. Several researchers have confirmed that there are clear differences between e-government and e-commerce though. For instance, [28] they asserted that e-commerce customers are not the equivalent of citizens in e-government. Moreover, government acts as a representative of its citizens, while companies are in a competition with one another. Therefore, services offered by banks (i.e. private sector) cannot be considered as egovernment services.

Reference [29] described the history of the e-government project in Jordan. They return the slow progress in egovernment implementation in Jordan to the fact that the majority of the projects are not linked together or activated. From the authors' point of view, [29] utilised qualitative methodology in their research; however they did not mention how the collected data was analysed.

Reference [30] claimed that the use of e-government services will be increased by citizens if the websites is designed carefully. Furthermore, [30] suggested that designers of egovernment services should allow the users to interact freely with the websites and this consequently will increase their intention to use e-government services.

To conclude, it seems to the researchers that the existing body of literature relating e-government in Jordan focused on issues such as intention to use e-government services, ecommerce transactions as part of e-government, narrative story of the development of e-government project in Jordan, the weaknesses of the ministries websites. However, none of the above mentioned literature addressed the reasons behind the failure of the project, hence the aim of this paper. The next section will discuss the qualitative methodology that will be utilised to provide more insight on the reasons of this failure.

\section{Research Methodology}

A qualitative method was applied in this research in order to gain rich understanding of such reasons. The employed data collection method was semi-structured interviews with public sector employees. According to [31], interviews of this nature of research tend to reach a point of data saturation after interviewing about eight individuals. Therefore, a total of eight employees were interviewed, these included three from MOICT and five from other ministries involved with the MOICT with the project. Questions were open in nature, allowing each interviewee to articulate his/her viewpoints as to why s/he felt the e-government programme can be categorised as total failure [21]. Secondary data, such as newspaper articles, were also utilised where there is relevant information to e-government programme.

Strauss and Corbin variant of grounded theory [32] was used as data analysis tool. This variant was chosen because of its recognition of the use and influence of existing technical literature, and the availability of strong guidance in its application [33]. Open coding was followed by axial coding which was followed by selective coding. Through this sequence several reasons behind the failure of e-government project in Jordan were identified; more discussion will be provided in the next section of this paper.

\section{Results AND Discussion}

The following factors have been identified as a core reasons behind the failure of e-government project in Jordan, these are as follows:

\section{A. economic situation}

From the grounded theory analysis, difficulties in the economic situation in Jordan emerged as a very strong reason behind the failure of e-government project.

The following are a sample of quotations from the interview transcripts that explicitly or implicitly refer to economic situation and its impact. An interviewee in the ministry of finance mentioned:

"Deficit in the government budget is always predominant, as an employee in the Ministry of Finance, I never remember that there is money surplus. So how such projects will be succeeded"

Lack of funding was a persistent barrier to the development in e-government project in developing countries [34]. However, in Jordan the issue is quite different because lack of funding represent constant problem, not only for e-government project, but also for other projects unlike ICT. The above interviewee added:

"Even if the money is available I don't think the e-government will be taken as high priority over any other important projects or initiatives" 
Therefore, it is obvious that the failure in e-government implementation in Jordan may not be solved in the short run; this is due to the fact that lack of funding in the government budget is persistent for several years.

\section{B. corruption}

Corruption was also identified as a major reason behind the failure of e-government project in Jordan. All interviewees asserted that unless government fight corruption, none of the government project will be succeeded. They refer to the corruption as an important reason for not being a civilised country (i.e. Jordan). One interviewee claimed:

"You know how many millions have been stolen by officials even by security ones"

As [35] confirmed, Jordan score in the corruption perception index is 48 (Scores range from 0 (highly corrupt) to 100 (very clean)). Moreover, Jordan score in the control of corruption was 0.040348086 (Point estimates range from about -2.5 to 2.5. Higher values correspond to better governance outcomes) in 2010 which reflects perceptions of the extent to which public power is exercised for private gain. These statistics confirmed that corruption in Jordan is widely spread and practiced by public sector employees. Corruption is not only resulted in e-government failure, but also many projects have failed as a result of it.

Furthermore, two interviewees from ministry of Planning and International Cooperation, and ministry of Social Development said:

"The corruption is reached to e-government department itself. The salaries are very high in comparison to other salaries in other ministries"

Ironically, citizens expect from the e-government programme to fight corruption in government departments. However, corruption have experienced and practiced in the ministries that supposed to fight it.

\section{Constant changing in ICT's ministers}

Among the issues revealed by interviewees in which represent one of the major reasons behind the failure of the project is the continual changing of ICT ministers and officials. The interviewees explicitly stated that ministerial positions are unstable, and ministers usually stay in office for only a few months. An interviewee in the ministry of Communication and Information Technology stated:

"Up to this year (2013), I have worked with 9 ministers. Some of them give priority to developing the e-government project; while others held it back. You can notice that every minister has different priorities"

In short, ministers do not have much time to make any improvements in the project. A project of this nature (i.e. national project) needs a long time to reach completion, and consequently the constant change of officials and/or ministers in Jordan, hinders progress on the project and as a result cannot be completed.

According to [36] the continual changing in official positions over 18 months further impacted negatively to the efficiency of the e-government implementation, the case that applied to Jordan.

\section{Lack of awareness on e-government}

The majority of the interviewees claimed that some employees in the government department are unaware of what e-government means. One interviewee asserted:

"Some of the public sector employees believe that $e$ government is another name of the IT department"

Another interviewee stated:

"It is a big problem when you meet some employees who think that we are going to computerise the departments as a mean of e-government"

This result was mentioned in [37] as government officials in developing world are focusing on the technology, rather than information when implementing e-government. To conclude, there is no general agreement among employees concerning the concept e-government, and therefore government employees might deal with the project as a process of computerisation rather than dealing with it by its real nature.

\section{CONCLUSION}

The aim of this paper was to uncover the reasons behind what so-called total failure in e-government project in Jordan. [21, p2] categorises e-government initiatives into three camps:

- Total failure: the initiative was never implemented or was implemented but immediately abandoned.

- Partial failure: major goals for the initiative were not attained and/or there were significant undesirable outcomes.

- Success: most stakeholder groups attained their major goals and did not experience significant undesirable outcomes.

As this paper has shown that since fourteen years of launching the program, only three services have been provided electronically. Jordanian government has decided to freeze the working on e-government programme and stop all egovernment projects in other ministries, until determining new to be suitable for Jordanian context [38] [39]. This research has suggested, however, that government should take into consideration the above argument of why such project has failed. Without addressing the above issues, it is unclear whether Jordan will be able to implement e-government or not. Economic situation, corruption, constant changing in ICT ministers, and lake of awareness of e-government, considered by interviewees to be core factors behind the failure of egovernment implementation in Jordan, as shown in this paper. Further research could be interesting to investigate how to overcome the above factors, so Jordan can be moved from total failure into partial one.

\section{REFERENCES}

[1] R. K. Kanaan, "Making sense of e-government implementation in Jordan: A qualitative investigation". Unpublished doctoral dissertation, De Montfort University, Leicester, UK, 2009.

[2] M. Yildiz, "E-government research: reviewing the literature, limitations, and ways forward". Government Information Quarterly, 24(3): pp.646665, 2007. 
[3] United Nations, "E-government survey, from e-government to connected governance". New York, 2008

[4] Z. Liao, \& M.T. Cheung, "Internet-based e-banking and consumer attitudes: an empirical study". Information and Management, Vol. 39, Issue. 4, pp.283-295, 2002.

[5] C. Leitner, "E-Government in europe: the state of affairs". Presented at e-government 2003 conference, Como, Italy, 7-8 July, 2003.

[6] CapGemini and TNO Consulting, "Does egovernment pay off!" EUREXEMP- final report, final version, 2004.

[7] United Nations, "Benchmarking e-government: a global perspective", Assessing the Progress of the UN Member States. United Nations DPEPA and ASPA, 2001

[8] V. Ndou, "E-government for developing countries: opportunities and challenges". The Electronic Journal on Information Systems in Developing Countries. Vol.18, Issue.1, pp.1-24, 2004.

[9] [9] T. Carbo, \& J. Williams, "Models and metrics for evaluating local electronic government systems and services. Electronic Journal of Egovernment, Vol. 2, Issue. 2 pp.95-104, 2004.

[10] M.M. Reynolds, \& M. Regio, "Egovernment as a catalyst in the information age, microsoft e-government initiatives", 2001 Available at: www.netcaucus.org/books/egov2001//pdf/EGovIntr.pdf. Date of Access 1 August 2013, 2001.

[11] M.E. Cook, M.F. LaVigne, C.M. Pagano, S.S. Dawes, \& T.A. Pardo, "making a case for local e-government". Center for Technology in Government, 2002.

[12] IDABC eGovernment Observatory, "The impact of eGovernment on competitiveness, growth and jobs", 2005. Available at: http://europa.eu.int/idabc/egovo. Date of access June, 10, 2013.

[13] J. Seifert, "A primer on e-government: sectors, stages, opportunities, and challenges of online governance". Report for Congress, 2003.

[14] World Bank, "The E-government handbook for developing countries". A project of InfoDev and the Center for Democracy and Technology, 2002.

[15] K. Layne, \& J. Lee, "Developing fully functional e-government: a four stage model". Government Information Quarterly. Vol. 18, Issue 2, pp.122-136, 2001.

[16] Deloitte Research, "At the dawn of e-government, the citizen as customer", 2000, Available at http://www.egov.vic.gov.au/pdfs/egovernment.pdf. Date of access 1 October 2013.

[17] ESCWA, "Promoting e-government applications towards an information society in escwa member countries". Western Asia Preparatory Conference for the World Summit on the Information Society (WSIS) Beirut, 4-6 February, 2003.

[18] J.S. Hiller, \& F. Belanger, "Privacy strategies for electronic government". E-Government Series. Arlington, VA: PricewaterhouseCoopers Endowment for the Business of Government, 2001.

[19] M. R. Muhammad, "Managing the implementation of e-government in malaysia: a case of e-syariah". Australian Journal of Basic and Applied Sciences, 7(8): pp.92-99, 2013.

[20] D. Dada, "The failure of e-government in developing countries: a literature review". The Electronic Journal on Information Systems in Developing Countries, 26, 7, pp.1-10, 2006
[21] R. Heeks, "Most egovernment-for-development projects fail: how can risks be reduced". iGovernment Working Paper Series. University of Manchester, 2003.

[22] CIA, "The world factbook". Available at: https://www.cia.gov/library/publications/the-worldfactbook/geos/jo.html. Date of Access 1 November 2013.

[23] MOICT, "E-government program: vision \& mission". Available at: http://www.moict.gov.jo/en-us/egovernmentprogram/visionmission.aspx Date of Access 25 November 2013.

[24] A. Al-Omari, \& H. Al-Omari, "E-government readiness assessment model". Journal of Computer Science 2 (11): pp.841-845, 2006.

[25] M. Al-Shboul, \& I. Alsmadi, “ Jordan e-government challenges and progresses". International Journal of Advanced Corporate Learning, Volume 3, Issue 1, 2010.

[26] M. Al-Zoubi, T. Sam, \& L. Eam, "E-Government adoption among businesses in Jordan". Academic Research International, Volume 1, Issue 1, 2011.

[27] M. Al-Zoubi, T. Sam, \& L. Eam, "Analysis of e-government adoption and organization performance in the jordan businesses sector". Academic Research International, Volume 1, Issue 3, 2011.

[28] B.C. Stahl, "The ethical problem of framing e-government in terms of ecommerce". Electronic Journal of E-Government. Vol. 3, Issue. 2, pp.77-86, 2005.

[29] S. Khasawneh, Y. Jalghoum, O. Harfoushi, \& R. Obiedat, "EGovernment program in jordan: from inception to future plans". International Journal of Computer Science Issues, Vol. 8, Issue 4, No 1, 2011.

[30] F.T. Qutaishat, “Users' perceptions towards website quality and its effect on intention to use e-government services in Jordan". International Business Research; Vol. 6, No. 1, 2013.

[31] R. K. Yin, "Case study research: Design and methods". California, USA, Sage Publications. Thousand Oaks, 2003.

[32] A. Strauss, \& J. Corbin, "Basics of qualitative research: grounded theory procedures and techniques", Sage, London, 1990.

[33] C. Fidler, R. Kanaan, \& S. Rogerson, "Barriers to e-government implementation in jordan: the role of wasta". International Journal of Technology and Human Interaction, Vol. 7, No. 2 April-June, 2011.

[34] J. Choudrie, V. Weerakkody \& S. Jones, "Realizing e-government in the uk: rural and urban challenges". The Journal of Enterprise Information Management, Vol. 18, Issue. 5, pp.568-585, 2005.

[35] Transparency International, "Transparency international; the global coalition against corruption". Available at: http://www.transparency.org/country\#JOR_DataResearch_SurveysIndic es. Date of Access 25 November 2013.

[36] J. Seifert, \& G. Bonham, "The transformative potential of e-government in transactional democracies". Washington, D.C., Congressional Research Service, 2004.

[37] United Nation, "UN global e-government readiness report, toward access for opportunity". New York, 2004.

[38] Sarayanews, "Online newspaper". Available at http://www.sarayanews.com/index.php?page=article\&id=215947. Date of Access 21 November 2013.

[39] Maqar News, "Online newspaper" Available at http://maqar.com/?id=31794 Date of Access 21 November 2013. 